\title{
Rape-seed meal toxicity in gnotobiotic rats: influence of a whole human faecal flora or single human strains of Escherichia coli and Bacteroides vulgatus
}

\author{
BY SYLVIE RABOT, LIONELLE NUGON-BAUDON, PIERRE RAIBAUD \\ AND ODETTE SZYLIT \\ Unité d'Ecologie et de Physiologie du Système Digestif, Centre de Recherches de Jouy, \\ Institut National de la Recherche Agronomique, 78352 Jouy-en-Josas Cédex, France
}

(Received 6 January 1992 - Accepted 7 September 1992)

\begin{abstract}
Gnotobiotic growing rats harbouring either a whole human faecal flora or single human strains of Escherichia coli (EM0) or Bacteroides vulgatus (BV8H1) were fed for 7 weeks on semi-synthetic diets in which the protein source was either soya-bean meal (SM) or rape-seed meal (RM). For each bacterial status the RM-diet group was compared with the control group fed on the SM diet. The association of human faecal flora with the RM diet was responsible for reduced feed intake and reduced weight gain, an enlargement of the liver and thyroid and a decrease in both thyroxine and triiodothyronine plasma levels. The association of the $B$. vulgatus BV8H1 strain with the RM diet reproduced all these effects, except that triiodothyronine plasma levels were not significantly modified. Rats inoculated with the $E$. coli EM0 strain and fed on the RM diet exhibited a goitre and lowered thyroxine and triiodothyronine plasma levels. These results show that the human intestinal microflora may be involved in glucosinolate metabolism when cruciferous vegetables are consumed by man. The specificity of the symptoms observed according to the rat bacterial status supports the hypothesis that bacteria yield specific toxic glucosinolate derivatives according to their enzymic potential.
\end{abstract}

Rape-seed meal: Gnotobiotic rats: Human intestinal flora

Cruciferous plants (cabbage, turnip, Brussels sprouts, cauliflower, rape etc.) are commonly present in human and animal diets. They contain glucosinolates (thioglycoside compounds) that are hydrolysed by vegetal or bacterial thioglycosidases (myrosinases) into derivatives responsible for undesirable side-effects such as depletion of feed intake and growth rate, enlargement of target organs (liver, kidneys, thyroid glands), liver haemorrhages and thyroid hormonal disorders (Fenwick et al. 1983; Bell, 1984). The nature and the severity of these symptoms vary according to the animal species (Bourdon et al. 1981; Butler et al. 1982; Vermorel et al. 1987, 1988).

In man, epidemiological surveys show a correlation between endemic goitre and the consumption of important amounts of cruciferous vegetables or milk from cows fed on brassicaceous crops (Clements, 1955; Michajlovskij et al. 1969; Mitjavila, 1986). Moreover, experimental studies show that the ingestion of cruciferous vegetables or of glucosinolates or glucosinolate derivatives can significantly reduce radioactive I uptake by the thyroid glands (Greer \& Astwood, 1948; Langer et al. 1971). However, other findings do not indicate thyroid troubles in volunteers fed on Brussels sprouts (McMillan et al. 1986).

In contrast to these undesirable properties, feeding cruciferous vegetables or glucosinolate derivatives can modify endogenous detoxication processes (McDanell et al. 1989; Nugon-Baudon et al. 1990 a) and thus, may interfere in a positive way with the 
metabolism of chemical carcinogens (Stoewsand et al. 1988) or more generally of toxic chemical compounds.

These phenomena should receive consideration since cruciferous intakes, which vary considerably according to geographical region, sex, age-group or income, may be associated with ingestion of large amounts of glucosinolates in some circumstances (Benns et al. 1978; Mullin \& Sahasrabudhe, 1978; Sones et al. 1984).

Greer \& Deeney (1959) were the first to suggest a role for the intestinal microflora in glucosinolate hydrolysis in vivo. This hypothesis was later reinforced by Oginsky et al. (1965) who showed that human faecal bacterial strains belonging to the Enterobacteriaceae were able to convert progoitrin into goitrin in vitro. Experiments using germ-free and conventional rats and chickens fed on rape-seed-meal-based diets gave definitive evidence of the responsibility of the intestinal flora in the release of glucosinolate derivatives in vivo (Nugon-Baudon et al. 1988); indeed, whereas both conventional rats and chickens fed on the rape-seed-meal-based diet exhibited usual glucosinolate-linked symptoms, no toxic effect was observed in their germ-free counterparts receiving the same diet; for each bacterial status, animals receiving a glucosinolate-free diet were used as controls. Furthermore, each of the whole microflora sources has specific effects when determined using gnotobiotic rats harbouring a whole chicken flora (Nugon-Baudon et al. 1988). Recently, a Lactobacillus strain isolated from the crop of a chicken was shown to induce a goitre in gnotobiotic rats fed on a rape-seed-meal diet (Nugon-Baudon et al. 1990b). However, most of the bacteria involved in these phenomena remain unidentified.

The initial aim of the present work was to study the effects of cruciferous vegetables in gnotobiotic rats harbouring a whole human faecal flora. This mimetic model is indeed an excellent simulator of what could happen in a human digestive tract (Mallett et al. 1987; Debure et al. 1989). Thereafter, we looked for specific myrosinase (EC 3.2.3.1)-like activity of individual bacterial strains belonging to this flora, challenging them in gnotobiotic rats fed on a cruciferous vegetable-based diet. Therefore, two strains from our laboratory collection were chosen: the first strain was an Escherichia coli strain, since Enterobacteriaceae strains have previously been demonstrated to have activity towards progoitrin in vitro (Oginsky et al. 1965); the second strain was a Bacteroides vulgatus strain, as it belongs to the predominant species of the human faecal flora (Finegold et al. 1983).

\section{EXPERIMENTAL}

\section{Experimental diets}

Two semi-synthetic diets were used, being isonitrogenous and isoenergetic (Table 1). In one diet the protein fraction was supplied by soya-bean meal (SM diet). In the other, soya-bean meal was substituted by rape-seed meal (RM diet). Dehulled 00 rape-seed meal (Darmor) containing $36.7 \mu \mathrm{mol}$ glucosinolates/g dry matter was supplied by Centre Technique Interprofessionnel des Oléagineux Métropolitains, Paris, France. Pelleted diets packed in double-vacuum bags were sterilized by irradiation at $40 \mathrm{kGy}$. The glucosinolate content of the irradiated rape-seed meal was determined using a GLC method (Centre Technique Interprofessionnel des Oléagineux Métropolitains, 1987) (Table 2).

\section{Animals: inoculation and maintenance}

Three groups of twelve male germ-free Fischer 344 rats weighing about $80 \mathrm{~g}$ at the beginning of trials were used. Each group was housed in separate Trexler-type isolators fitted with a rapid transfer system (La Calhène, Vélizy, France).

Whole faecal flora from a healthy adult male subject was administered orally (oesophagal tubing) to each rat in the first group (HFF rats), using $1 \mathrm{ml}$ of freshly passed stools $(10 \mathrm{~g} / 1$; 
Table 1. Composition of diets $(\mathrm{g} / \mathrm{kg})$

\begin{tabular}{|c|c|c|}
\hline Protein source... & Rape-seed meal & Soya-bean meal \\
\hline $\begin{array}{l}\text { Rape-seed meal } \\
\text { (Darmor 00) }\end{array}$ & $390 \cdot 00$ & - \\
\hline Soya-bean meal & - & $276 \cdot 00$ \\
\hline Maize starch & $531 \cdot 40$ & $576 \cdot 00$ \\
\hline Maize oil & $20 \cdot 00$ & $20 \cdot 00$ \\
\hline Lysine hydrochloride & 0.60 & - \\
\hline Vitamin mixture & 18.00 & 18.00 \\
\hline Mineral mixture & $40 \cdot 00$ & 40.00 \\
\hline Cellulose & - & $70 \cdot 00$ \\
\hline $\begin{array}{l}\text { Protein }(\mathrm{N} \times 6.25) \\
(\mathrm{g} / \mathrm{kg} \text { dry matter })\end{array}$ & 145.00 & $150 \cdot 00$ \\
\hline $\mathrm{ME}(\mathrm{kJ} / \mathrm{kg}$ dry matter) & 15270 & 15440 \\
\hline
\end{tabular}

ME, metabolizable energy

Table 2. Glucosinolate (GLS) content of irradiated Darmor rape-seed meal ( $\mu \mathrm{mol} / \mathrm{g}$ dry matter)

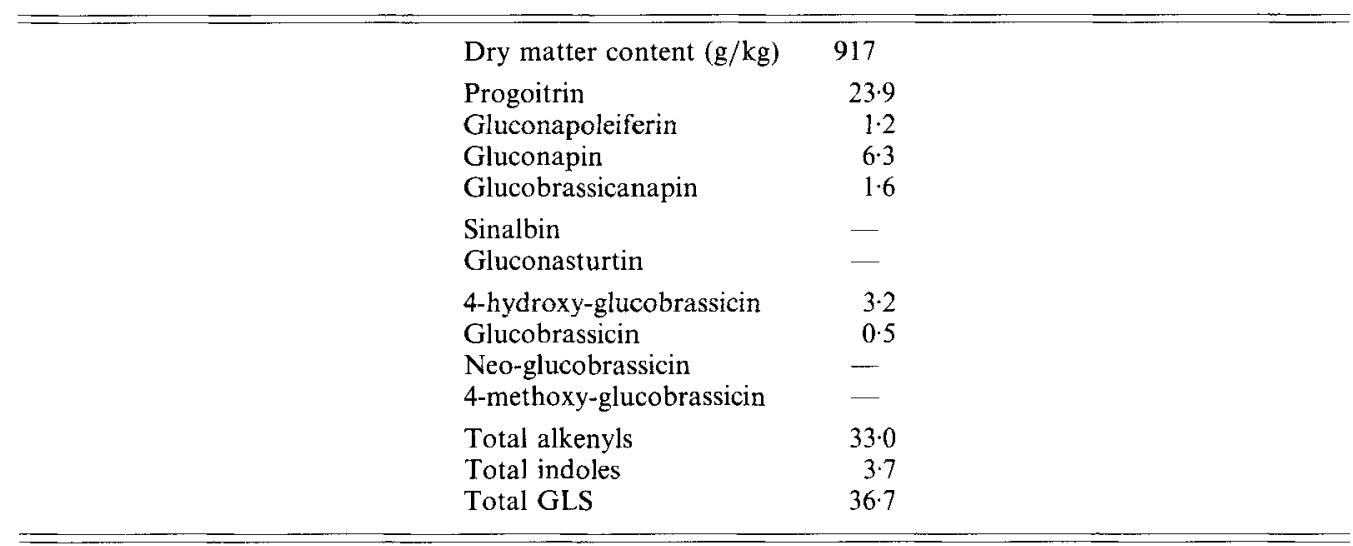

prepared in an anaerobic chamber (Aranki et al. 1969) and transferred into the isolator in a butyl-rubber-stoppered tube). An E. coli strain (EM0) (Duval-Iflah et al. 1981) was administered orally to each rat in the second group using $1 \mathrm{ml}$ of an overnight aerobic culture on a liquid medium, $\mathrm{pH} 7 \cdot 0$, containing $(\mathrm{g} / 1)$ : tryptone (Difco, Detroit, MI, USA) 5, nutrient broth (Difco) 5, yeast extract (Difco) $1, \mathrm{NaCl} 5$. A B. vulgatus strain (BV8H1) was administered orally to each rat in the third group, using $1 \mathrm{ml}$ of a $24 \mathrm{~h}$ anaerobic culture on a brain-heart infusion (Difco), $\mathrm{pH} 7 \cdot 0$, with added yeast extract (Difco) $5 \mathrm{~g} / \mathrm{l}$, and hemin (Sigma, La Verpillière, France) $5 \mathrm{mg} / 1$. For each bacterial status, animals were then randomly divided into two subgroups of six animals each; one group received the control diet (SM diet) and the other group received the RM diet. Animals were fed ad lib. and were given sterilized $\left(20 \mathrm{~min}, 120^{\circ}\right)$ tap-water to drink.

The room temperature was $21^{\circ}$ with a $12 \mathrm{~h}$ light-dark cycle. Animal weight and feed intake were measured once weekly for 7 weeks. 


\section{Bacteriological methods}

Bacterial population levels in rats inoculated with a single strain were measured weekly by culture of faecal samples serially diluted 10 -fold in a liquid medium, $\mathrm{pH} 7 \cdot 0$, containing (g/l) casein enzymic-hydrolysate (USBC, Cleveland, Ohio) 2, yeast extract (Difco) $2, \mathrm{NaCl}$ $5, \mathrm{KH}_{2} \mathrm{PO}_{4}$ 1. E. coli EM0 was grown aerobically for $24 \mathrm{~h}$ at $37^{\circ}$ on an agar medium, pH 7.0, containing (g/l): tryptone (Difco) 5 , nutrient broth (Difco) 5 , yeast extract (Difco) 1, $\mathrm{NaCl} 5$, agar (Touzart et Matignon, Vitry-sur-Seine, France) 10. B. vulgatus BV8H1 was grown anaerobically for $48 \mathrm{~h}$ at $37^{\circ}$ on brain-heart infusion (Difco), $\mathrm{pH} 7 \cdot 0$, with added yeast extract (Difco) $5 \mathrm{~g} / \mathrm{l}$, hemin (Sigma) $5 \mathrm{mg} / \mathrm{l}$, Bitek agar (Difco) $14 \mathrm{~g} / \mathrm{l}$.

\section{Sample collection}

The animals were anaesthetized with chloroform 7 weeks after inoculation. Blood samples were collected by cardiac puncture in order to obtain a sample of plasma which was stored at $-20^{\circ}$ until analysed. Rats were then killed using chloroform and the glucosinolate target organs (liver, kidneys and thyroid glands) were removed quickly and weighed after removal of surrounding fat. For groups inoculated with a single species the gnotobiotic status and the bacterial population levels in the caecal contents were checked as already described for faecal samples (see p. 326).

\section{Hormone assays}

Plasma tetraiodothyronine (T4) and triiodothyronine (T3) concentrations were determined in duplicate using an ELISA method (Immunodiagnostics Enzymun Tests T4 and T3; Boehringer Mannheim, Meylan, France). These Enzymun kits, originally designed for use with human plasma, have been used previously (Nugon-Baudon et al. 1990 $a, b$ ); data obtained for rats using these kits are consistent with those reported by other authors using different methods (Ukai \& Mitsuma, 1977; Jordan et al. 1980; Vermorel et al. 1986, 1988).

\section{Statistical analyses}

Bacteriological data are expressed as $\log _{10}$ of the bacterial faecal or caecal populations. Anatomical data are expressed as $\mathrm{g}$ or $\mathrm{mg} / \mathrm{kg}$ body weight.

Results are expressed as means with their standard errors. For each bacterial status, the RM-diet group was compared with the control group fed on the SM diet using Student's $t$ test. Statistical significance was at $P<0.01$ level.

\section{RESULTS}

Caecal bacterial counts in rats inoculated with a single species

Whatever the strain, the RM diet did not significantly modify the caecal population levels since caecal counts were 9.7 (SE 0.7) v. 10.2 (SE 0.2) for EM0-SM-fed rats and EM0-RMfed rats respectively, and $9 \cdot 1$ (SE 0.2) v. $9 \cdot 7$ (SE 0.2) for BV8H1-SM-fed rats and BV8H1-RM-fed rats respectively.

\section{Effects of RM diet on growth curve and feed intake in relation to the bacterial status}

When HFF rats were fed on the RM diet, growth rate was dramatically decreased from the second week post-inoculation (Table 3). Cumulative weight gain at the end of the experiment was $56 \%$ lower in this group compared with the control group fed on the SM diet. This was correlated with a reduced feed intake: $10 \mathrm{~g} / \mathrm{rat}$ per $\mathrm{d} v .19 \mathrm{~g} / \mathrm{rat}$ per $\mathrm{d}$ in the RM and SM groups respectively, as calculated from the intake values for the whole group.

In rats harbouring the EM0 strain, growth rates were similar whatever the diet (Table 4). Feed intake was $15 \mathrm{~g} /$ rat per $\mathrm{d} v .19 \mathrm{~g} /$ rat per $\mathrm{d}$ in the RM and SM groups respectively. 
Table 3. The effect of diet $\dagger$ on growth curve, target organ weight and thyroid hormones in gnotobiotic rats harbouring a whole human faecal florat.

(Mean values with their standard errors)

\begin{tabular}{|c|c|c|c|c|}
\hline \multirow{3}{*}{ No. of animals... } & \multicolumn{4}{|c|}{ Diet } \\
\hline & \multicolumn{2}{|c|}{$\begin{array}{c}\text { Soya-bean meal } \\
6\end{array}$} & \multicolumn{2}{|c|}{$\begin{array}{c}\text { Rape-seed meal } \\
6\end{array}$} \\
\hline & Mean & SE & Mean & $\mathrm{SE}$ \\
\hline Initial body wt $(\mathrm{g})$ & 82 & 13 & 81 & 13 \\
\hline \multicolumn{5}{|l|}{ Cumulative wt gain (g) } \\
\hline \multicolumn{5}{|l|}{ Time (weeks) } \\
\hline 1 & 29 & 2 & 29 & 2 \\
\hline 2 & 68 & 2 & $42 * * *$ & 2 \\
\hline 3 & 97 & 4 & $47^{* * *}$ & 2 \\
\hline 4 & 132 & 4 & $55^{* * *}$ & 4 \\
\hline 5 & 152 & 7 & $62 * * *$ & 7 \\
\hline 6 & 178 & 7 & $73^{* * *}$ & 11 \\
\hline 7 & 181 & 7 & $79 * * *$ & 13 \\
\hline Liver $(\mathrm{g} / \mathrm{kg}$ body $\mathrm{wt})$ & $38 \cdot 2$ & $1 \cdot 1$ & $45 \cdot 1 * * *$ & $2 \cdot 0$ \\
\hline Kidneys (g/kg body wt) & $8 \cdot 2$ & 0.4 & $8 \cdot 5$ & 0.9 \\
\hline Thyroid ( $\mathrm{mg} / \mathrm{kg}$ body wt) & 36 & $2 \cdot 0$ & $169 * * *$ & 9 \\
\hline Tetraiodothyronine (nmol/1 plasma) & $54 \cdot 9$ & $14 \cdot 3$ & $28 \cdot 6^{* *}$ & $5 \cdot 1$ \\
\hline Triiodothyronine (nmol/l plasma) & $1 \cdot 71$ & $0-16$ & $1 \cdot 33^{* *}$ & $0 \cdot 20$ \\
\hline
\end{tabular}

Mean values were significantly different from those for soya-bean-meal diet: ${ }^{* *} P<0.01,{ }^{* * *} P<0.001$.

$\uparrow$ For details of diets, see p. 324 and Tables 1 and 2.

$\ddagger$ For details of experimental procedures, see pp. 324-326.

On the contrary, growth rate was strongly decreased in BV8H1-treated rats fed on the RM diet compared with their SM counterparts (Table 5). Depletion of the weight gain at the end of trials reached $72 \%$. This result was correlated with a reduced feed intake: $9 \mathrm{~g} / \mathrm{rat}$ per $\mathrm{d} v .19 \mathrm{~g} /$ rat per $\mathrm{d}$ in the RM and SM groups respectively.

\section{Effects of the RM diet on target organ weights in relation to bacterial status}

Compared with their SM counterparts, HFF-RM-fed rats exhibited an enlargement of the liver $(+18 \%)$ and thyroid $(+369 \%)$, whereas no effect was seen on kidney weight (Table $3)$.

In gnotobiotic rats, the effects of the RM diet on target organ weights were different according to the strain: rats harbouring the EM0 strain only suffered from a thyroid enlargement $(+202 \%)$ (Table 4$)$, whereas inoculation with the $\mathrm{BV} 8 \mathrm{Hl}$ strain led to a dramatic goitre $(+572 \%)$ and an enlargement of the liver $(+14 \%$; Table 5$)$. Kidney weight was not modified in any case.

Effects of the RM diet on thyroid hormones in relation to the bacterial status

A significant decrease in both T4 and T3 plasma concentrations ( -48 and $-22 \%$ respectively) was observed in the HFF-RM-fed group compared with its SM counterpart (Table 3).

In the same way, T4 and T3 plasma levels were respectively 44 and $29 \%$ lower in the EM0-RM-fed group than in the EM0-SM-fed group (Table 4). 
Table 4. The effect of diet $\dagger$ on growth curve, target organ weight and thyroid hormones in gnotobiotic rats harbouring a human strain of Escherichia colił

(Mean values with their standard errors)

\begin{tabular}{|c|c|c|c|c|}
\hline \multirow{3}{*}{ No. of animals... } & \multicolumn{4}{|c|}{ Diet } \\
\hline & \multicolumn{2}{|c|}{$\begin{array}{c}\text { Soya-bean meal } \\
6\end{array}$} & \multicolumn{2}{|c|}{$\underset{6}{\text { Rape-seed meal }}$} \\
\hline & Mean & $\mathrm{SE}$ & Mean & $\mathrm{SE}$ \\
\hline Initial body wt (g) & 79 & 4 & 75 & 4 \\
\hline \multirow{2}{*}{\multicolumn{5}{|c|}{ Cumulative wt gain (g) }} \\
\hline & & & & \\
\hline 1 & 19 & 4 & 34 & 2 \\
\hline 2 & 63 & 4 & 69 & 4 \\
\hline 3 & 95 & 7 & 89 & 7 \\
\hline 4 & 130 & 9 & 114 & 11 \\
\hline 5 & 163 & 11 & $137^{* *}$ & 9 \\
\hline 6 & 175 & 9 & 155 & 11 \\
\hline 7 & 184 & 9 & 165 & 9 \\
\hline Liver ( $\mathrm{g} / \mathrm{kg}$ body wt) & $40 \cdot 1$ & $0 \cdot 2$ & $40 \cdot 4$ & $1 \cdot 1$ \\
\hline Kidneys $(\mathrm{g} / \mathrm{kg}$ body wt) & $7 \cdot 7$ & $0 \cdot 4$ & $7 \cdot 3$ & 0.7 \\
\hline Thyroid (mg/kg body wt) & 48 & 5 & $145^{* * *}$ & 18 \\
\hline Tetraiodothyronine (nmol/1 plasma) & $55 \cdot 7$ & $4 \cdot 7$ & $31 \cdot 0^{* * * *}$ & $2 \cdot 2$ \\
\hline Triiodothyronine (nmol/l plasma) & $1 \cdot 43$ & $0 \cdot 18$ & $1.01 * *$ & $0 \cdot 20$ \\
\hline
\end{tabular}

Mean values were significantly different from those for soya-bean-meal diet: ${ }^{* *} P<0 \cdot 01,{ }^{* * *} P<0-001$

$\uparrow$ For details of diets, see p. 324 and Tables 1 and 2 .

$\$$ For details of experimental procedures, see pp. 324-326.

As for the BV8H1-treated rats, a significant depletion in T4 levels occurred in the RMgroup $(-43 \%)$; the T3 concentration was also strongly decreased $(-29 \%)$ but this effect was not significant (Table 5).

\section{DISCUSSION}

The whole human faecal flora, as well as single strains isolated from it, displays a myrosinase-like potential when implanted in the rat digestive tract. Thus, it may be assumed that the intestinal microflora could be involved in the thyroid disorders sometimes observed in humans consuming cruciferous vegetables (Clements, 1955; Michajlovskij et al . 1969; Mitjavila, 1986).

Furthermore, changes in feed intake and growth curve and liver hypertrophy observed in HFF rats, as well as in rats inoculated with the BV8H1 strain, show that this myrosinaselike potential is not restricted to the development of thyroid disorders. The discrepancies between these effects and what has been so far described in man could arise from the origin and the high level of glucosinolates used in our experimental diets, which are different from what is usually encountered in human diets. Actually these experimental conditions, i.e. a high level of glucosinolates always supplied by the same source of cruciferous vegetables, were chosen to favour as high bacterial myrosinase-like activities as possible and to compare them whatever the origin of the flora (rat, chicken, man etc.) harboured by the gnotobiotic rats (Nugon-Baudon et al. 1988).

HFF-RM-fed rats exhibited symptoms different from those observed in conventional rodents (Vermorel et al. 1987; Nugon-Baudon et al. 1988, 1990a). Indeed we did not 
Table 5. The effect of diet $\dagger$ on growth curve, target organ weight and thyroid hormones in gnotobiotic rats harbouring a human strain of Bacteroides vulgatus $\$$

(Mean values with their standard errors)

\begin{tabular}{|c|c|c|c|c|}
\hline \multirow{3}{*}{ No. of animals... } & \multicolumn{4}{|c|}{ Diet } \\
\hline & \multicolumn{2}{|c|}{$\begin{array}{c}\text { Soya-bean meal } \\
6\end{array}$} & \multicolumn{2}{|c|}{$\underset{6}{\text { Rape-seed meal }}$} \\
\hline & Mean & $\mathrm{SE}$ & Mean & $\mathrm{SE}$ \\
\hline Initial body wt $(\mathrm{g})$ & 109 & 2 & 116 & 4 \\
\hline \multirow{2}{*}{\multicolumn{5}{|c|}{$\begin{array}{l}\text { Cumulative wt gain }(\mathrm{g}) \\
\text { Time (weeks) }\end{array}$}} \\
\hline & & & & \\
\hline 1 & 24 & 2 & 30 & 4 \\
\hline 2 & 60 & 4 & $44 * * *$ & 2 \\
\hline 3 & 99 & 7 & $42^{* * *}$ & 2 \\
\hline 4 & 134 & 9 & $45^{* * *}$ & 7 \\
\hline 5 & 158 & 9 & $49 * * *$ & 4 \\
\hline 6 & 175 & 9 & $48^{* * *}$ & 7 \\
\hline 7 & 187 & 11 & $53 * * *$ & 9 \\
\hline Liver (g/kg body wt) & $35 \cdot 6$ & 0.9 & $40 \cdot 7 * * *$ & $1 \cdot 1$ \\
\hline Kidneys (g/kg body wt) & $7 \cdot 1$ & 0.4 & $8 \cdot 0$ & 0.7 \\
\hline Thyroid (mg/kg body wt) & 36 & 2 & $242 * * *$ & 20 \\
\hline Tetraiodothyronine (nmol/1 plasma) & $71 \cdot 3$ & 6.7 & $40 \cdot 6^{* *}$ & $12 \cdot 3$ \\
\hline Triiodothyronine (nmol/l plasma) & 1.44 & $0 \cdot 16$ & $1 \cdot 02$ & 0.49 \\
\hline
\end{tabular}

Mean values were significantly different from those for soya-bean-meal diet: ${ }^{* *} P<0 \cdot 01,{ }^{* * *} P<0 \cdot 001$.

$\dagger$ For details of diets, see p. 324 and Tables 1 and 2.

$\ddagger$ For details of experimental procedures, see pp. 324-326.

reproduce hypertrophy of the kidneys. Therefore, it is likely that the discrepancies in undesirable effects related to the animal species do not result from a host-related sensitivity but from the nature of the intestinal microflora. This confirms the conclusion from a previous experiment comparing conventional rats with rats harbouring a whole chicken microflora (Nugon-Baudon et al. 1988).

In rats inoculated with either the EM0 strain or the BV8H1 strain the caecal population levels were high and were not modified by the protein source of the diet. The toxic sideeffects of the RM diet differed according to the bacterial strain. The association of the BV8H1 strain with the RM diet reproduced all the effects observed in HFF-RM-fed rats; however, mean T3 plasma concentrations in the BV8H1-SM-fed group and the BV8H1-RM-fed group were not significantly different, due to the large variation in the values for the RM group. The association of the EM0 strain with the RM diet only reproduced some of the findings obtained for HFF-RM-fed rats, i.e. a dramatic goitre associated with hypothyroidism. This is in agreement with the results of Oginsky et al. (1965), who demonstrated an in vitro conversion of progoitrin into goitrin by members of the family Enterobacteriaceae, since goitrin is thought to be the major antithyroid compound in cruciferous vegetables (Greer, 1962; Mitjavila, 1986). Moreover, since T4 and $\mathrm{T} 3$ plasma concentrations were strongly reduced in EM0-RM-fed rats whereas growth rate was not altered, the relationships between the decrease in weight gain and thyroid disorders are probably less exclusive and more complex than generally assumed. Thus, specific but still unknown bacterial glucosinolate derivatives may be involved in the decrease in weight gain of BV8H1-RM-fed rats. 
In conclusion, the specificity of the symptoms in relation to the bacterial status of the rat supports the hypothesis that bacteria yield specific toxic glucosinolate derivatives in relation to specific enzymic properties. These findings are a new step in the exploration of the mechanisms involved in glucosinolate metabolism.

This work was supported by grants from the French Ministry of Agriculture and Forestry and from Centre Technique Interprofessionel des Oléagineux Métropolitains (CETIOM), Paris, France. The authors thank CETIOM for providing the Darmor rape-seed meal and Dr Ribaillier and his co-workers (CETIOM, Ardon, France) for glucosinolate analysis of the rape-seed meal. They are grateful to Dr Nicoli (Instituto de Ciencias Biológicas, Belo Horizonte, Brazil) for kindly isolating and providing the B. vulgatus $\mathrm{BV} 8 \mathrm{H} 1$ strain.

\section{REFERENCES}

Aranki, A., Syed, S. A., Kenney, E. B. \& Freter, R. (1969). Isolation of anaerobic bacteria from human gingiva and mouse cecum by means of a simplified glove box procedure. Applied Microbiology 17, 568-576.

Bell, J. M. (1984). Nutrients and toxicants in rapeseed meal: a review. Journal of Animal Science 58, 996-1010.

Benns, G. B., Hall, J. W. \& Beare-Rogers, J. L. (1978). Intake of brassicaceous vegetables in Canada. Canadian Journal of Public Health 69, $64-66$.

Bourdon, D., Perez, J. M. \& Baudet, J. J. (1981). Utilisation de nouveaux types de tourteaux de colza par le porc en croissance-finition: influence des glucosinolates et du dépelliculage (New types of rapeseed meal fed to growing-finishing pigs: influence of glucosinolates and dehulling). Journées de la Recherche Porcine en France 13, 163-178.

Butler, E. J., Pearson, A. W. \& Fenwick, G. R. (1982). Problems which limit the use of rapeseed meal as a protein source in poultry diets. Journal of the Science of Food and Agriculture 33, 866 875.

Centre Technique Interprofessionnel des Oléagineux Métropolitains (1987). Analyse des graines oléagineuses (Analysis of oilseeds). Guide pratique AFNOR. Paris: CETIOM.

Clements, F. W. (1955). A thyroid blocking agent as a cause of endemic goitre in Tasmania: preliminary communication. Medical Journal of Australia 3, 369-371.

Debure, A., Colombel, J. F., Flourie, B., Rautureau, M. \& Rambaud, J. C. (1989). Comparaison de l'implantation et de l'activité métabolique d'une flore fécale de rat et d'une flore fécale humaine inoculées chez le rat axénique (Implantation and metabolic activity of rat and human fecal bacterial flora administered to germ-free rats). Gastroentérologie Clinique et Biologique 13, 25-31.

Duval-Iflah, Y., Raibaud, P. \& Rousseau, M. (1981). Antagonisms among isogenic strains of Escherichia coli in the digestive tracts of gnotobiotic mice. Infection and Immunity 34, 957-969.

Fenwick, G. R., Heaney, R. K. \& Mullin, W. J. (1983). Glucosinolates and their breakdown products in food and food plants. Critical Reviews in Food Science and Nutrition 18, 123-201.

Finegold, S. M., Sutter, V. L. \& Mathisen, G. E. (1983). Normal indigenous intestinal flora. In Human Intestinal Microffora in Health and Disease, pp. 3-31 [D. J. Hentges, editor]. New York: Academic Press.

Greer, M. A. (1962). The natural occurrence of goitrogenic agents. Recent Progress in Hormone Research 18, 187-219.

Greer, M. A. \& Astwood, E. B. (1948). The antithyroid effect of certain foods in man as determined with radioactive iodine. Endocrinology 43, 105-119.

Greer, M. A. \& Deeney, J. M. (1959). Antithyroid activity elicited by the ingestion of pure progoitrin, a naturally occurring thioglycoside of the turnip family. Journal of Clinical Investigation 38, 1465-1474.

Jordan, D., Rousset, B., Perrin, F., Fournier, M. \& Orgiazzi, J. (1980). Evidence for circadian variations in serum thyrotropin, 3,5,3'-triiodothyronine, and thyroxine in the rat. Endocrinology 107, 1245-1248.

Langer, P., Michajlovskij, N., Sedlak, J. \& Kutka, M. (1971). Studies on the antithyroid activity of naturally occurring L-5-vinyl-2-thiooxazolidone in man. Endokrinologie 57, 225-229.

McDanell, R., Mclean, A. E. M., Hanley, A. B., Heaney, R. K. \& Fenwick, G. R. (1989). The effect of feeding brassica vegetables and intact glucosinolates on mixed-function oxidase activity in the livers and intestines of rats. Food and Chemical Toxicology 27, $289-293$.

McMillan, M., Spinks, E. A. \& Fenwick, G. R. (1986). Preliminary observations on the effect of dietary Brussels sprouts on thyroid function. Human Toxicology 5, 15-19.

Mallett, A. K., Bearne, C. A., Rowland, I. R., Farthing, M. J. G., Cole, C. B. \& Fuller, R. (1987). The use of rats associated with a human faecal flora as a model for studying the effects of diet in the human gut microflora. Journal of Applied Bacteriology 63, 39-45.

Michajlovskij, N., Sedlak, J., Jusic, M. \& Buzina, R. (1969). Goitrogenic substances of kale and their possible relations to the endemic goitre on the island of Krk (Yugoslavia). Endocrinologia Experimentalis 3, 65-72.

Mitjavila, S. (1986). Substances naturelles nocives des aliments (Natural toxic compounds in food). Toxicologie et Sécurité des Aliments, pp. 129-157. Paris: Lavoisier et Apria. 
Mullin, W. J. \& Sahasrabudhe, M. R. (1978). An estimate of the average daily intake of glucosinolates via cruciferous vegetables. Nutrition Reports International 18, 273-279.

Nugon-Baudon, L., Rabot, S., Szylit, O. \& Raibaud, P. (1990a). Glucosinolate toxicity in growing rats: interactions with the hepatic detoxification system. Xenobiotica 20, 223-230.

Nugon-Baudon, L., Rabot, S., Wal, J. M. \& Szylit, O. (1990b). Interactions of the intestinal microflora with glucosinolates in rapeseed meal toxicity: first evidence of an intestinal Lactobacillus possessing a myrosinaselike activity in vivo. Journal of the Science of Food and Agriculture 52, 547-559.

Nugon-Baudon, L., Szylit, O. \& Raibaud, P. (1988). Production of toxic glucosinolate derivatives from rapeseed meal by intestinal microflora of rat and chicken. Journal of the Science of Food and Agriculture 43, $299-308$.

Oginsky, E. L., Stein, A. E. \& Greer, M. A. (1965). Myrosinase activity in bacteria as demonstrated by the conversion of progoitrin to goitrin. Proceedings of the Society for Experimental Biology and Medicine 119, $360-364$

Sones, K., Heaney, R. K. \& Fenwick, G. R. (1984). An estimate of the mean daily intake of glucosinolates from cruciferous vegetables in the UK. Journal of the Science of Food and Agriculture 35, 712-720.

Stoewsand, G. S., Anderson, J. L. \& Munson, L. (1988). Protective effect of dietary Brussels sprouts against mammary carcinogenesis in Sprague-Dawley rats. Cancer Letters 39, 199-207.

Ukai, M. \& Mitsuma, T. (1977). Plasma triiodothyronine, thyroxine and thyrotrophin levels in germfree rats. Experientia 34, 1095-1096.

Vermorel, M., Davicco, M. J. \& Evrard, J. (1987). Valorization of rapeseed meal. 3. Effects of glucosinolate content on food intake, weight gain, liver weight and plasma thyroid hormone levels in growing rats. Reproduction Nutrition Développement 27, 57-66.

Vermorel, M., Heaney, R. K. \& Fenwick, G. R. (1986). Nutritive value of rapeseed meal: effects of individual glucosinolates. Journal of the Science of Food and Agriculture 37, 1197-1202.

Vermorel, M., Heaney, R. K.\& Fenwick, G. R. (1988). Antinutritional effects of the rapeseed meals, Darmor and Jet Neuf, and progoitrin together with myrosinase, in the growing rat. Journal of the Science of Food and Agriculture 44, 321-334. 